\title{
Impact of ocean acidification and warming on the Mediterranean mussel (Mytilus galloprovincialis)
}

\author{
Frédéric Gazeau ${ }^{1,2} *$, Samir Alliouane ${ }^{1,2}$, Christian Bock ${ }^{3}$, Lorenzo Bramanti ${ }^{4,5}$, \\ Matthias López Correa ${ }^{6,7}$, Miriam Gentile ${ }^{8}$, Timo Hirse ${ }^{3}$, Hans-Otto Pörtner ${ }^{3}$ and Patrizia Ziveri ${ }^{9,10}$ \\ Sorbonne Universités, Université Pierre et Marie Curie Univ Paris 06, Unité Mixte de Recherche 7093, Laboratoire d'Océanographie de Villefranche, \\ Villefranche/Mer, France \\ ${ }^{2}$ Centre National de la Recherche Scientifique, Unité Mixte de Recherche 7093, Laboratoire d'Océanographie de Villefranche, Observatoire Océanologique, \\ Villefranche/Mer, France \\ ${ }^{3}$ Alfred-Wegener-Institute Helmholtz Zentrum für Polar und Meeresforschung, Am Handelshafen 12, D-27570 Bremerhaven, Germany \\ ${ }^{4}$ Sorbonne Universités, Université Pierre et Marie Curie Univ Paris 06, Unité Mixte de Recherche 8222, Laboratorio de Ecofisiología para la Conservación de \\ Bosques, Observatoire Océanologique, Banyuls/mer, France \\ ${ }^{5}$ Centre National de la Recherche Scientifique, Unité Mixte de Recherche 8222, Laboratorio de Ecofisiología para la Conservación de Bosques, Observatoire \\ Océanologique, Banyuls/mer, France \\ ${ }^{6}$ GeoZentrum Nordbayern, Universität Erlangen-Nürnberg, Erlangen, Germany \\ 7 German University of Technology in Oman, Halban Campus, Muscat, Sultanate of Oman \\ ${ }^{8}$ Consejo Superior de Investigaciones Científicas, Institut de Ciencies del Mar, Barcelona, Spain \\ ${ }^{9}$ Universitat Autònoma de Barcelona, Institut de Ciència i Tecnologia Ambientals, Barcelona, Spain \\ ${ }^{10}$ Institució Catalana de Recerca i Estudis Avançats, Barcelona, Spain
}

\section{Edited by:}

Robinson W. Fulweiler, Boston University, USA

Reviewed by:

Claudia R. Benitez-Nelson,

University of South Carolina, USA

Emily Carrington, University of

Washington, USA

\section{*Correspondence:}

Frédéric Gazeau, Laboratoire

d'Océanographie de Villefranche, Centre National de la Recherche

Scientifique - Université Pierre et

Marie Curie and Unité Mixte de

Recherche 7093, 06230

Villefranche-sur-mer, France

e-mail:f.gazeau@obs-vlfr.fr
In order to assess the effects of ocean acidification and warming on the Mediterranean mussel (Mytilus galloprovincialis), specimens were reared in aquarium tanks and exposed to elevated conditions of temperature $\left(+3^{\circ} \mathrm{C}\right)$ and acidity $(-0.3 \mathrm{pH}$ units) for a period of 10 months. The whole system comprised a factorial experimental design with 4 treatments ( 3 aquaria per treatment): control, lowered $\mathrm{pH}$, elevated temperature, and lowered $\mathrm{pH} /$ elevated temperature. Mortality was estimated on a weekly basis and every 2 months, various biometrical parameters and physiological processes were measured: somatic and shell growth, metabolic rates and body fluid acid-base parameters. Mussels were highly sensitive to warming, with $100 \%$ mortality observed under elevated temperature at the end of our experiment in October. Mortality rates increased drastically in summer, when water temperature exceeded $25^{\circ} \mathrm{C}$. In contrast, our results suggest that survival of this species will not be affected by a $\mathrm{pH}$ decrease of $\sim 0.3$ in the Mediterranean Sea. Somatic and shell growth did not appear very sensitive to ocean acidification and warming during most of the experiment, but were reduced, after summer, in the lowered $\mathrm{pH}$ treatment. This was consistent with measured shell net dissolution and observed loss of periostracum, as well as uncompensated extracellular acidosis in the lowered $\mathrm{pH}$ treatment indicating a progressive insufficiency in acid-base regulation capacity. However, based on the present dataset, we cannot elucidate if these decreases in growth and regulation capacities after summer are a consequence of lower $\mathrm{pH}$ levels during that period or a consequence of a combined effect of acidification and warming. To summarize, while ocean acidification will potentially contribute to lower growth rates, especially in summer when mussels are exposed to sub-optimal conditions, ocean warming will likely pose more serious threats to Mediterranean mussels in this region in the coming decades.

Keywords: ocean acidification, ocean warming, Mediterranean mussels, growth, survival, Mediterranean Sea

\section{INTRODUCTION}

During the last 150 years, human activities, through the combustion of fossil fuels (oil, gas, and coal), have led to a dramatic release of carbon dioxide $\left(\mathrm{CO}_{2}\right)$ to the Earth's atmosphere. The accumulation of $\mathrm{CO}_{2}$ impacts the radiative forcing, thereby warming the atmosphere and the ocean. The surface ocean has warmed from 1971 to 2010 by $0.11^{\circ} \mathrm{C}$ per decade (Rhein et al., 2013), with maximal rates recorded on average in the coastal zone $\left(0.18^{\circ} \mathrm{C}\right.$; Lima and Wethey, 2012). Depending on the future emission scenario, surface ocean temperatures are projected to warm in the top $100 \mathrm{~m}$ by about 0.6 to $2.0^{\circ} \mathrm{C}$ by 2100 (Collins et al., 2013). The oceans are not only absorbing a large amount of increased heat, but also about $25 \%$ of anthropogenic $\mathrm{CO}_{2}$ emissions (Le Quéré et al., 2009). This massive $\mathrm{CO}_{2}$ input greatly impacts seawater chemistry, leaving a surface ocean imprint. These changes are referred to as "ocean acidification" (OA) because increased $\mathrm{CO}_{2}$ lowers seawater $\mathrm{pH}$ (i.e., increases its acidity). The $\mathrm{pH}$ in ocean surface waters has already decreased by 0.1 units since the beginning of the industrial era, equivalent to an increased acidity of $26 \%$. According to recent projections, an 
additional decrease is expected by 2100 , ranging from 0.06 to 0.32 units, equivalent to an increased acidity of 15-110\%, depending on the considered emission scenario (Ciais et al., 2013).

The effects of OA on marine organisms have been studied over the past 20 years (Gattuso and Hansson, 2011), with particular attention to organisms producing calcareous structures. Indeed, while decreasing $\mathrm{pH}$ levels are expected to have profound impacts on the physiology and metabolism of marine organisms through a disruption of intercellular transport mechanisms (Pörtner et al., 2004), the seawater $\mathrm{pH}$ decrease will also lead to a decrease in the concentration of carbonate ions $\left(\mathrm{CO}_{3}^{2-}\right)$, one of the building blocks of calcium carbonate $\left(\mathrm{CaCO}_{3}\right)$, and likely alter the ability of calcifying organisms to precipitate $\mathrm{CaCO}_{3}$ (Gazeau et al., 2007). Being both ecologically and economically important species in the coastal zone, the body of literature on mollusks has grown substantially over recent years (see comprehensive review from Gazeau et al., 2013).

To date, very few studies have considered the impacts of OA in synergy with other environmental stressors such as warming, with contrasting results. Moreover, all these studies considered stable $\mathrm{pH}$ and/or temperature conditions although large daily and/or seasonal variations in these parameters are common features of coastal sites (Hofmann et al., 2011). For instance, Mackenzie et al. (2014) reported that Atlantic mussels (Mytilus edulis) were not impacted by a decrease of $\mathrm{pH}$ by 0.4 units, while these organisms were highly sensitive to a temperature increase of $4^{\circ} \mathrm{C}$. In contrast, Duarte et al. (2014) found that the Chilean mussel (Mytilus chilensis) was able to tolerate an increase in temperature of $4^{\circ} \mathrm{C}$ for 2 months but that shell growth was significantly affected by a decrease in $\mathrm{pH}$ of $\sim 0.2-0.3$ units. Additive effects of these two stressors have been highlighted in several studies (Talmage and Gobler, 2011; Hiebenthal et al., 2013) although with large variations between species and even developmental stages (Talmage and Gobler, 2011). Finally, Watson et al. (2012) and Ivanina et al. (2013) reported synergistic effects of these two stressors on the survival of the fluted giant clam (Tridacna squamosa), and on the shell hardness of Eastern oysters (Crassostrea virginica), and hard clams (Mercenaria mercenaria). Interestingly, Ivanina et al. (2013) showed that mortality of oysters was ameliorated under a warmer and more acidified scenario as compared to a warmer scenario only.

The Mediterranean mussel (Mytilus galloprovincialis) is one of the most cultivated bivalve species with a global production that has drastically increased in the last 50 years to reach a value of around 1 million tons in 2011, with China and Spain representing the most important producers: $\sim 700,000$ and $\sim 200,000$ tons, respectively (FAO, 2014). In the Mediterranean Sea, this bivalve is the third-most cultivated species in terms of production, after Seabass and Seabreams. The production is dominated by Italy and Greece with values in 2011 of $\sim 65,000$ and $\sim 20,000$ tons, respectively. The Spanish production occurs predominantly on the Atlantic coast (i.e., 98\%).

In the northwestern Mediterranean Sea, mean maximum summer temperatures have increased by about $1^{\circ} \mathrm{C}$ between 2002 and 2010 relative to the 1980-2000 average (Marba and Duarte, 2010) and a rapid warming of $2.8 \pm 1.1^{\circ} \mathrm{C}$ is expected by the end of the century (Jorda et al., 2012). In this region, high summer temperature levels already represent a problem for the rearing of mussels and farmers are obliged to sell their product before summer (Ramón et al., 2005). Moreover, the observed mean rate of OA is similar to that in Atlantic subtropical regions (Orr, 2011), with a $0.05-0.14$ decrease in seawater $\mathrm{pH}$ since the pre-industrial period (Touratier and Goyet, 2011) and projected to decrease by 0.3 units by the end of the century (Orr, 2011). In addition, Mediterranean coastal marine ecosystems are experiencing the synergistic effects of multiple climatic and non-climatic anthropogenic stressors such as chemical contaminants (The Mermex Group, 2011). In order to assess the potential combined effects of $\mathrm{OA}$ and warming on the Mediterranean mussel, we performed laboratory experiments in which mussels were exposed to elevated temperature $\left(+3^{\circ} \mathrm{C}\right)$ and acidity $(-0.3 \mathrm{pH}$ units $)$ in aquaria flushed with ambient seawater and thus against the background of natural variability for a period of 10 months.

\section{MATERIAL AND METHODS BIOLOGICAL MATERIAL AND EXPERIMENTAL SET-UP}

Mussels with a mean shell length of $45 \pm 5 \mathrm{~mm}$ were collected in the Delta del Ebro $\left(40^{\circ} 35^{\prime} 59^{\prime \prime} \mathrm{N} ; 0^{\circ} 41^{\prime} 21^{\prime \prime} \mathrm{E}\right)$ in November 2011 and directly brought to the Institute of Marine Science (Barcelona, Spain). Seawater, pumped from a depth of $10 \mathrm{~m}$ at proximity of the institute $(300 \mathrm{~m}$ from the coast), and filtered onto $50 \mu \mathrm{m}$, was continuously supplied to four $100 \mathrm{~L}$ header tanks at a minimal rate of $50 \mathrm{~L} \mathrm{~h}^{-1}$. The whole system comprised a factorial experimental design with 4 treatments (control, lowered $\mathrm{pH}$, elevated temperature, and lowered $\mathrm{pH} /$ elevated temperature), and 12 experimental aquaria (30 L) with 3 aquaria per treatment. From each header tank, seawater was delivered by gravity to the three experimental aquaria at a rate of ca. $15 \mathrm{~L} \mathrm{~h}^{-1}$ per aquarium (checked on a weekly basis with a flow meter). A small pump was installed in each aquarium in order to create some water movement. A total of 120 mussels were haphazardly placed in each aquarium. In the perturbation header tanks, $\mathrm{pH}$ and temperature were respectively decreased by $0.1 \mathrm{pH}$ units and increased by $1^{\circ} \mathrm{C} /$ week over 3 weeks, and thereafter maintained at a $\mathrm{pH}$ offset of $\sim-0.3$ and a temperature offset of $\sim+3^{\circ} \mathrm{C}$ for the duration of the experiment ( $\sim 10$ months). The $\mathrm{pH}$ offset was controlled by bubbling pure- $\mathrm{CO}_{2}$ in the corresponding header tanks using a continuous pH-stat system (IKS, Karlsbad, Aquastar). pH electrodes from the $\mathrm{pH}$-stat system were inter-calibrated on a weekly basis using a glass combination electrode (Metrohm, electrode plus) calibrated on the total scale using TRIS buffer solutions with a salinity of 35 (provided by A. Dickson, Scripps Institution of Oceanography, San Diego). The $+3^{\circ} \mathrm{C}$ offset was maintained with thermo-resistances $(2 \times 500 \mathrm{~W}$ per header tank $)$ controlled by a COREMA@temperature-regulation system. Twice a day, the seawater flow was stopped and mussels were fed with a commercial mixture of live Nannochloropsis oculata, Phaeodactylum tricornutum and Chlorella (DT's Live Marine Phytoplankton) at a final concentration of $\sim 4 \%$ mussel tissue dry weight, close to ingestion rates measured in situ by Galimany et al. (2011) in the area of collection. Mussel average tissue dry weight was estimated at the start of the experiment by weighing 10 randomly selected mussels after $24 \mathrm{~h}$ in an oven at $60^{\circ} \mathrm{C}$. Food quantity was adjusted in each aquarium based on the remaining number of mussels and considering a constant average tissue dry weight throughout the experiment. Seawater flow was restored once all phytoplankton 
had been filtered by the mussels ( $1-2 \mathrm{~h})$. Mortality of the mussels was recorded, dead mussels were removed and aquaria were cleaned on a weekly basis.

Seawater samples for total alkalinity $\left(A_{\mathrm{T}}\right)$ measurements were collected once a week in the ambient seawater header tank, filtered on GF/F membranes, immediately poisoned with $\mathrm{HgCl}_{2}$ and analyzed within 2 months at the Laboratoire d'Océanographie de Villefranche (France). $A_{\mathrm{T}}$ was determined potentiometrically using a Metrohm titrator (Titrando 80), and a glass electrode (Metrohm, electrode plus) calibrated using first NBS buffers ( $\mathrm{pH}$ 4.0 and $\mathrm{pH} 7.0$, to check that the slope was Nernstian) and then using TRIS buffer solutions (salinity 35, provided by A. Dickson, Scripps Institution of Oceanography, San Diego). Triplicate titrations were performed on $50 \mathrm{~mL}$ sub-samples at $25^{\circ} \mathrm{C}$ and $A_{\mathrm{T}}$ was calculated as described by Dickson et al. (2007). Titrations of standard seawater provided by A. Dickson (batch 106) yielded $A_{\mathrm{T}}$ values within $2.4 \mu \mathrm{mol} \mathrm{kg}{ }^{-1}$ of the nominal value $(S D=$ $1.2 \mu \mathrm{mol} \mathrm{kg}-1, n=32$ ). All parameters of the carbonate chemistry were determined from $\mathrm{pH}_{\mathrm{T}}, A_{\mathrm{T}}$, temperature and salinity using the $\mathrm{R}$ package seacarb (Lavigne et al., 2014).

\section{BIOMETRICS AND PHYSIOLOGICAL MEASUREMENTS}

Every 2 months, various biometrical parameters and physiological processes were measured. Shell length, shell weight and fresh weight were monitored on 20 haphazardly pre-labeled mussels per aquarium. Shell weight was measured using the buoyant weight technique (Spencer Davies, 1989). Net calcification, excretion and respiration rates were measured by incubating 3 haphazardly chosen mussels per aquarium in $300 \mathrm{~mL}$ respiration chambers for $3 \mathrm{~h}$. Temperature was maintained at the corresponding level for each treatment by plunging the respiration chambers in tanks with flowing experimental seawater. Mussels were not fed for a period of $6 \mathrm{~h}$ before the start of the incubations. Blanks containing only seawater were done at the start and at the end of the 10 -month exposure and showed that variations of any of the constituents due to microbial processes were less than $0.5 \%$ of the variations observed with mussels (data not shown). Respiration rates were estimated as the rate of oxygen concentrations decrease over the $3 \mathrm{~h}$ incubations by means of continuous measurements (1 measurement every $5 \mathrm{~s}$ ) with fiber-optic oxygen microsensors (PreSens@). Oxygen decrease was always linear during the $3 \mathrm{~h}$ incubations and concentrations never dropped below $70 \%$ of saturation. Before and after the $3 \mathrm{~h}$ incubations, $\mathrm{pH}_{\mathrm{T}}$ was measured with a glass electrode calibrated using TRIS buffers (see above) and seawater was sampled for the measurements of ammonium $\left(\mathrm{NH}_{4}\right)$ and $A_{\mathrm{T}} \cdot \mathrm{pH}_{\mathrm{T}}$ decrease during the incubations averaged $0.14 \pm 0.05$. For $\mathrm{NH}_{4}, 20 \mathrm{~mL}$ of seawater were sampled, filtered on $0.2 \mu \mathrm{m}$ and immediately frozen at $-20^{\circ} \mathrm{C}$. Measurements were performed within 2 days at the Institute of Marine Science, using an autoanalyzer. For $A_{\mathrm{T}}$, sampling and measurements were performed as described above. Tissue dry weights of the incubated mussels were measured after $24 \mathrm{~h}$ in an oven at $60^{\circ} \mathrm{C}$ and all rates were expressed as per gram of tissue dry weight (g DW). Net calcification rates were calculated based on the observed difference in $A_{\mathrm{T}}$ before and after incubation, corrected for the effect of excretion on $A_{\mathrm{T}}$ (Wolf-Gladrow et al., 2007), following the equation:

$$
G=\frac{\mathrm{E}-\Delta A_{\mathrm{T}}}{2}
$$

where $G$ are net calcification rates (in $\mu$ mol $\mathrm{CaCO}_{3} \mathrm{~g} \mathrm{DW}^{-1} \mathrm{~h}^{-1}$ ), $\mathrm{E}$ are excretion rates (in $\mu \mathrm{mol} \mathrm{N} \mathrm{g} \mathrm{DW} \mathrm{NW}^{-1} \mathrm{~h}^{-1}$ ) and $\Delta A_{\mathrm{T}}$ are the observed $A_{\mathrm{T}}$ changes (in $\mu \mathrm{mol} \mathrm{g} \mathrm{DW} \mathrm{DW}^{-1} \mathrm{~h}^{-1}$ ).

Within a maximum of 5 days from the metabolism measurements, an analysis of haemolymph and extrapallial fluid $\mathrm{pH}$ and $p \mathrm{CO}_{2}$ was conducted on another batch of mussels ( $n=6$ individuals) from all four groups, except in October when no measurements were performed. A volume of $0.2-1 \mathrm{~mL}$ of haemolymph and extrapallial fluid was sampled using a syringe equipped with cannulas of $0.6 \times 30$ and $0.6 \times 80 \mathrm{~mm}$ size, respectively. The body fluids were transferred directly to Eppendorf caps and placed into a thermostated water bath (Lauda R100) set to the temperature determined in the aquaria prior to sampling. Body fluid $\mathrm{pH}$ was measured using a micro $\mathrm{pH}$ electrode (Mettler) combined with a $\mathrm{pH}$ meter (WTW $\mathrm{pH} 3310$ ) and calibrated to the specific temperature. Fluid $p \mathrm{CO}_{2}$ were determined by calculation (Pörtner et al., 1990, 2010) from measurements of total $\mathrm{CO}_{2}$ in a carbon dioxide analyzer (Corning 965) operating in a linear range from 0.71 to $11.36 \mathrm{mM}$ using a $\mathrm{NaHCO}_{3}$ standard $\left(1 \mathrm{~g} \mathrm{~L}^{-1}\right)$ for calibration. The sample volume was $0.1 \mathrm{~mL}$. Total $\mathrm{CO}_{2}$ was determined in relation to standard solutions set to similar concentrations to compensate for a potential drift of the sensor.

\section{PERIOSTRACUM ANALYSES}

At the end of the experimental period, shells from live mussels were sampled for quantification of periostracum cover. As all mussels were dead in the elevated temperature aquaria at the end of the experiment, only shells from the control and the lowered $\mathrm{pH}$ treatments were analyzed. Five random specimens from each treatment were used for area quantification and valve dimensions (height, width, and inflation) were additionally measured with a digital caliper as secondary control. Visual inspections of these shells showed areas without periostracum, preferentially in the umbo portions of the shells. In order to quantify systematic differences between the two treatments, the outline of periostracum-free areas and of the shell perimeter were redrawn in CorelDraw from scaled high-resolution pictures, placed on a constant reference area of $1441 \times 1441$ pixel (equivalent to $10 \times$ $10 \mathrm{~cm}$ ) and converted into black and white images. Pixel count area quantifications were carried out in ImageJ $1.47 \mathrm{v}$ (http:// imagej.nih.gov/ij/) and periostracum loss (\%) is given relative to the total shell area.

\section{STATISTICS}

Growth rates (shell weight, shell length, and fresh weight) were compared based on the analyses of variance of linear regression models performed with the $\mathrm{R}$ software. Regarding mortality, metabolic rates, and acid-base parameters (haemolymph and extrapallial fluid $\mathrm{pCO}_{2}$ and $\mathrm{pH}$ ), due to the low number of replicates, permutational multivariate analyses of variance (Permanova) were performed using the $\mathrm{R}$ package RVAideMemoire (Hervé, 2014) to test for differences between the 4 treatments. These analyses were performed considering two orthogonal fixed factors $\left(\mathrm{pH}_{\mathrm{T}}\right.$ and temperature) and one blocking 


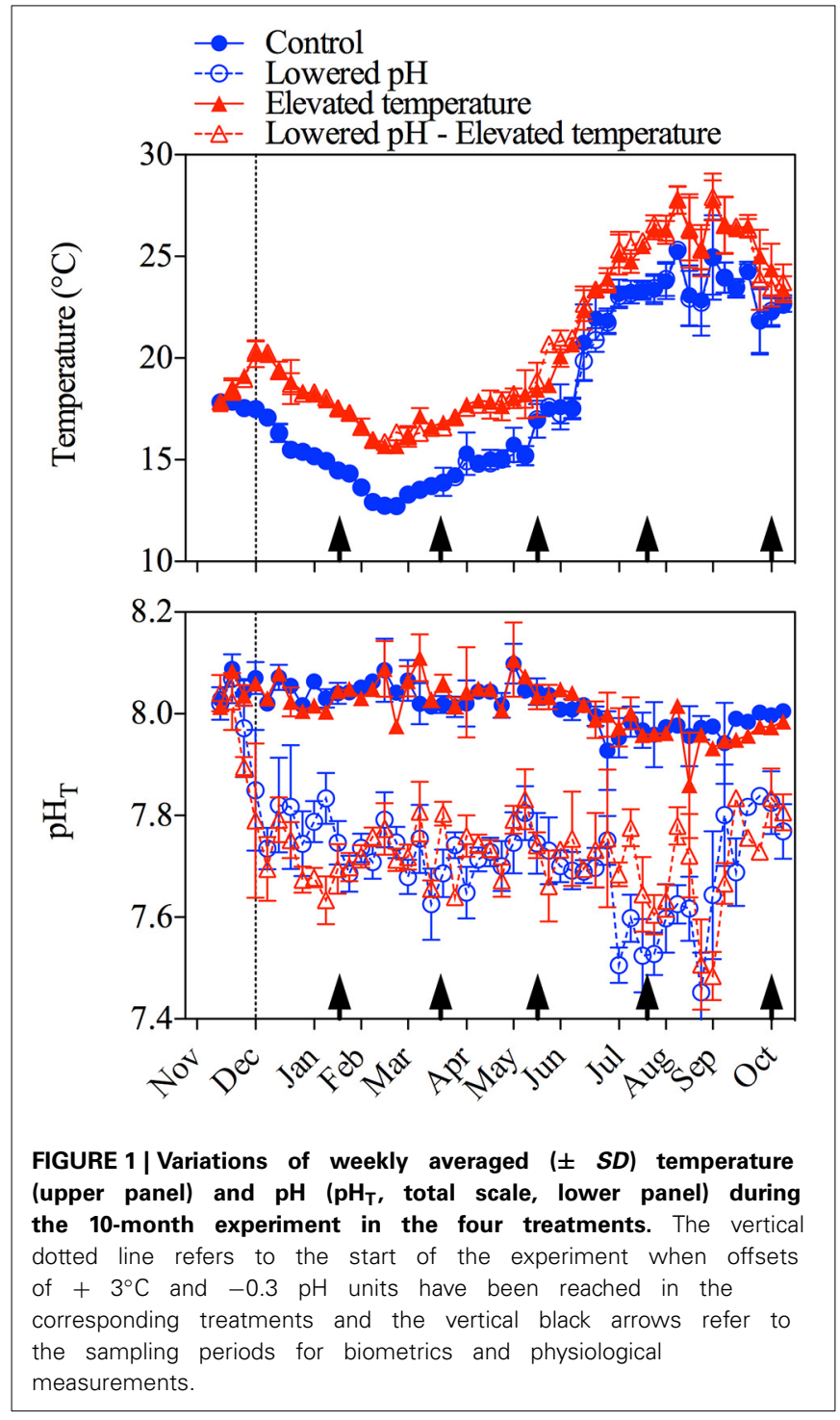

factor (time) over 1000 permutations and a significant effect was considered when $p<0.05$. Differences between control and lowered $\mathrm{pH}$ treatments in terms of periostracum cover at the end of the experiment was tested using a non-parametric MannWhitney test on $\mathrm{R}$, and considered significant at the risk $\alpha=5 \%$.

\section{RESULTS}

Environmental parameters to which the mussels were exposed are presented in Figure 1 and Table 1 . Weekly averaged temperature naturally varied between $\sim 12$ and $\sim 25^{\circ} \mathrm{C}$ with minimal levels recorded in February and maximal levels reached in August. Temperature was maintained with mean offsets of respectively $2.7 \pm 0.6$ and $2.6 \pm 0.6^{\circ} \mathrm{C}$ in the lowered $\mathrm{pH} /$ elevated temperature and elevated temperature treatments, as compared to the control. $\mathrm{pH}_{\mathrm{T}}$ was relatively constant in the ambient $\mathrm{pH}$ treatments $(8.01 \pm 0.04$ and $8.01 \pm 0.06$ in the control and elevated temperature treatments, respectively). In the lowered $\mathrm{pH}$ treatments, offsets of $-0.31 \pm 0.08$ and $-0.30 \pm 0.07$ were observed in the lowered $\mathrm{pH}$ and lowered $\mathrm{pH} /$ elevated temperature treatments, respectively. However, as can be seen in Figure 1, the $\mathrm{pH}$ regulation was less efficient in summer (July/August) with observed average offsets of $-0.40 \pm 0.1$ and $-0.32 \pm 0.1$ in the lowered $\mathrm{pH}$ and lowered $\mathrm{pH} /$ elevated temperature treatments, respectively. Notwithstanding, aragonite saturation states differed among treatments with minimal values in the lowered $\mathrm{pH} / \mathrm{ambient}$ temperature treatment, but seawater remained oversaturated with respect to this mineral in all treatments during the entire experiment.

Cumulative mortality rates were below $20 \%$ for all treatments until the end of June and started to increase abruptly in the elevated temperature treatments when temperature levels reached $\sim 25^{\circ} \mathrm{C}$ or more (Figure 2). Temperature was the main driver for this increased mortality (Permanova, $p<0.001$, $n=38$ ), with no significant effect of $\mathrm{pH}$, either combined, or in isolation (Permanova, $p>0.05, n=38$, in both cases). In the ambient temperature treatments, regardless of the $\mathrm{pH}$ level, mortality rates started to increase after August, when temperature

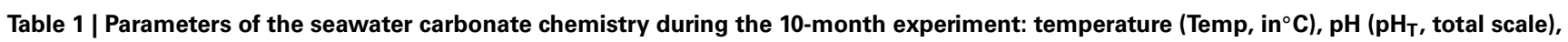
partial pressure of carbon dioxide $\left(\mathrm{pCO}_{2}\right.$, in $\left.\mu \mathrm{atm}\right)$, total inorganic carbon concentration $\left(C_{\mathrm{T}}\right.$, in $\left.\mu \mathrm{mol} \mathrm{kg}^{-1}\right)$, and saturation state of the seawater with respect to aragonite $\left(\Omega_{a}\right)$, and calcite $\left(\Omega_{c}\right)$.

\begin{tabular}{|c|c|c|c|c|c|c|c|c|}
\hline Treatment & Temp & $\Delta$ Temp & $\mathbf{p H}_{\mathbf{T}}$ & $\Delta \mathrm{pH}_{\mathrm{T}}$ & $\mathrm{pCO}_{2}$ & $C_{T}$ & $\mathbf{\Omega}_{\mathrm{a}}$ & $\Omega_{c}$ \\
\hline \multirow[t]{2}{*}{ Control } & 18.2 & - & 8.01 & - & 476 & 2274 & 2.9 & 4.5 \\
\hline & $(12.7 ; 25.2)$ & & $(7.93 ; 8.10)$ & & $(375 ; 601)$ & $(2201 ; 2326)$ & $(2.5 ; 3.4)$ & $(3.9 ; 5.2)$ \\
\hline \multirow[t]{2}{*}{ Lowered pH } & 18.2 & -0.1 & 7.71 & -0.31 & 1090 & 2422 & 1.6 & 2.5 \\
\hline & $(12.7 ; 25.3)$ & $(-1.1 ; 0.1)$ & $(7.45 ; 7.84)$ & $(-0.52 ;-0.14)$ & $(760 ; 2051)$ & $(2308 ; 2517)$ & $(1.1 ; 2.4)$ & $(1.7 ; 3.7)$ \\
\hline Elevated temperature & 20.8 & 2.6 & 8.01 & 0.0 & 479 & 2252 & 3.2 & 4.8 \\
\hline \multirow[t]{2}{*}{ Lowered $\mathrm{pH}$-elevated temperature } & 20.9 & 2.7 & 7.72 & -0.30 & 1060 & 2401 & 1.8 & 2.8 \\
\hline & $(15.9 ; 27.9)$ & $(1.2 ; 3.6)$ & (7.48; 7.83) & $(-0.49 ;-0.16)$ & $(772 ; 1922)$ & $(2292 ; 2484)$ & $(1.3 ; 2.8)$ & $(2.0 ; 4.1)$ \\
\hline
\end{tabular}

The difference of the perturbation and the control treatments in terms of $\mathrm{pH}_{T}\left(\Delta p H_{T}\right)$ and temperature $(\Delta T e m p)$ is also reported. For each parameter, the average value is reported as well as the range (min; max). Total alkalinity ranged between 2485 and $2565 \mu \mathrm{mol} \mathrm{kg}^{-1}$ and averaged $2540 \mu \mathrm{mol} \mathrm{kg}^{-1}$. Salinity ranged between 37.8 and 38.1 and averaged 38.0 . 


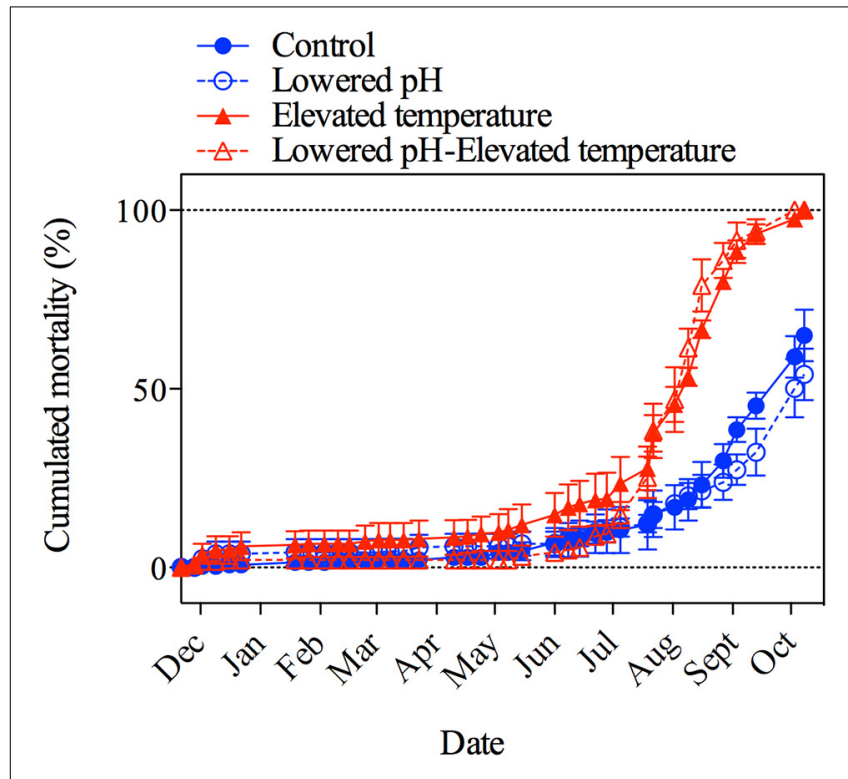

FIGURE 2 | Cumulative number of dead mussels as expressed as a percentage of the initial population (120 individuals per aquarium) in the four treatments during the 10-month experiment. Error bars correspond to standard errors (SE; 3 aquaria per treatment: $n=3$ ).

levels also reached $\sim 25^{\circ} \mathrm{C}$. A mortality of $100 \%$ was recorded by the end of the experiment (October) in the elevated temperature treatments, while in ambient temperature treatments mortality was $60 \%$.

Growth parameters are presented in Figure 3. Cumulated growth in terms of shell length, fresh weight, and shell weight were relatively small with maximum growth by the end of the experiment of $1.4 \pm 0.1 \mathrm{~mm}, 0.9 \pm 0.1 \mathrm{~g}$, and $0.20 \pm 0.1 \mathrm{~g}$, respectively. Note that, as all mussels exposed to elevated temperature levels were dead before the last sampling period in October, no data are available for these treatments. We applied linear models to describe these data, revealing that growth in shell length and in fresh weight was not affected by lowered $\mathrm{pH}$ or elevated temperature (Table 2 ). In contrast, growth in shell weight was significantly reduced by both of these perturbations, although without cumulative effects. In October, mussel shell weights even decreased in the lowered $\mathrm{pH}$ treatment, a decrease that was accompanied by a decrease in fresh weight and shell length (Figure 3).

Respiration, excretion and net calcification rates are presented in Figure 4. As no data were collected in October for mussels exposed to elevated temperature levels (no specimen survived), two distinct Permanova tests have been applied: 1) for all treatments and for the period January to July and 2) for ambient temperature treatments (testing only the effect of lowered $\mathrm{pH}$ ) for the whole experimental period (see Table 3 ). Respiration rates significantly increased at elevated temperature (Table 3), and with mean values, for the period January/July, of $21.03 \pm 3.3$ and $24.2 \pm 4.8 \mu \mathrm{mol} \mathrm{O}_{2} \mathrm{~g} \mathrm{DW}^{-1} \mathrm{~h}^{-1}$ in the ambient and increased temperature treatments, respectively. Excretion rates mean values were $3.3 \pm 1.0 \mu \mathrm{mol} \mathrm{N} \mathrm{g} \mathrm{DW}{ }^{-1} \mathrm{~h}^{-1}$ for all treatments and sampling periods and, as for respiration rates, significantly increased at elevated temperature $(2.6 \pm 0.7$ vs. $3.3 \pm 0.9 \mu \mathrm{mol} \mathrm{N} g$
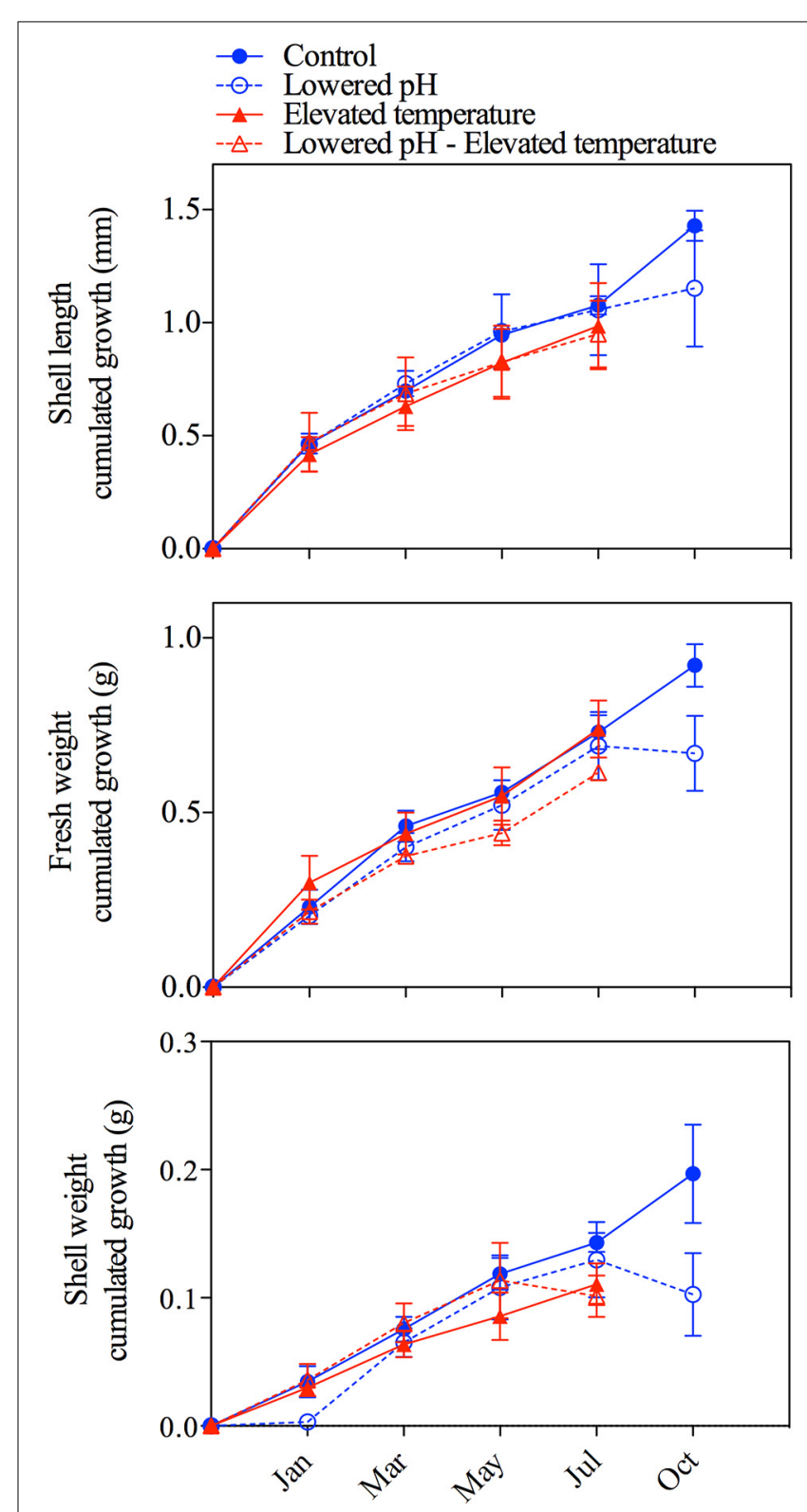

FIGURE 3 | Cumulative growth in shell length (mm; upper panel), fresh weight (g, central panel) and shell weight (g; lower panel) in the four treatments during the 10-month experiment. Error bars correspond to standard errors (SE; maximum of 20 measures per aquarium, 3 aquaria per treatment: $n=60$ in January and decreases with time due to mortality).

$\mathrm{DW}^{-1} \mathrm{~h}^{-1}$ in the ambient and increased temperature treatments, respectively, for the period January/July). Excretion of ammonium was responsible, on average, for $63.3 \pm 0.2 \%$ of the observed $A_{\mathrm{T}}$ variations, and confirmed that a correction of the alkalinity anomaly technique was necessary for this species. Net calcification rates significantly decreased in the lowered $\mathrm{pH} /$ elevated temperature treatment. Most of the time, net calcification rates were significantly above 0 , except in May and July in the lowered $\mathrm{pH} /$ elevated temperature treatment and in October in the ambient $\mathrm{pH}$ and lowered $\mathrm{pH}$ treatments. In October, negative values 
Table 2 | Analysis of variance of the linear models fitted to the growth of mussels exposed to the four treatments ( $n=932 ; 5$ time points, 2 temperature levels, $2 \mathrm{pH}$ levels).

\begin{tabular}{|c|c|c|c|c|}
\hline Source of variation & $d f$ & MS & $\boldsymbol{F}$ & $p$ \\
\hline \multicolumn{5}{|l|}{ SHELL LENGTH } \\
\hline Time & 1 & 635 & 1761 & $<2.2 \times 10^{-16}$ \\
\hline Time $\times$ Temperature & 1 & 0.24 & 0.68 & 0.41 \\
\hline Time $\times \mathrm{pH}_{\mathrm{T}}$ & 1 & 0.45 & 1.24 & 0.27 \\
\hline Time $\times$ Temperature $\times \mathrm{pH}_{\mathrm{T}}$ & 1 & 0.05 & 0.13 & 0.72 \\
\hline Residuals & 943 & 0.36 & & \\
\hline \multicolumn{5}{|l|}{ FRESH WEIGHT } \\
\hline Time & 1 & 243 & 2455 & $<2.2 \times 10^{-16}$ \\
\hline Time $\times$ Temperature & 1 & 0.07 & 0.73 & 0.39 \\
\hline Time $\times \mathrm{pH}$ & 1 & 0.14 & 1.41 & 0.24 \\
\hline Time $\times$ Temperature $\times \mathrm{pH}$ & 1 & 0.01 & 0.14 & 0.71 \\
\hline Residuals & 941 & 0.10 & & \\
\hline \multicolumn{5}{|l|}{ SHELL WEIGHT } \\
\hline Time & 1 & 7.80 & 1084 & $<2.2 \times 10^{-16}$ \\
\hline Time $\times$ Temperature & 1 & 0.03 & 3.99 & $0.04^{*}$ \\
\hline Time $\times \mathrm{pH}$ & 1 & 0.03 & 4.19 & $0.04^{*}$ \\
\hline Time $\times$ Temperature $\times \mathrm{pH}$ & 1 & 0.00 & 0.48 & 0.49 \\
\hline Residuals & 924 & 0.007 & & \\
\hline
\end{tabular}

All regression slopes were significantly different from 0 . Asterisks denote significant effects of the considered perturbation at the risk $\alpha=0.05$.

(net dissolution) were measured in the lowered $\mathrm{pH}$ treatment, however as a consequence of the low replication and large associated errors, the difference between ambient and lowered $\mathrm{pH}$ treatments were not statistically significant.

Figure 5 depicts the $\mathrm{pH}$ changes in haemolymph and extrapallial fluid from January to July. The analysis of variance showed a significant impact of seawater $\mathrm{pH}$ only for haemolymph $\mathrm{pH}$ (Table 3), and no impacts of temperature on both fluids in terms of $\mathrm{pH}$. Except for the mean haemolymph $\mathrm{pH}$ of the elevated temperature group, $\mathrm{pH}$ in haemolymph and extrapallial fluid started with values below 7.4 in all groups. $\mathrm{pH}$ values in all groups increased from January to March, but always remained much lower than seawater $\mathrm{pH}$. After March, $\mathrm{pH}$ values in both haemolymph and extrapallial fluid decreased over time, with a larger decrease at lowered $\mathrm{pH}$ levels. In July, a large difference ( $\sim 0.16$ units) in extracellular $\mathrm{pH}$ of the haemolymph had developed between the two normocapnic groups and the two groups under elevated $\mathrm{CO}_{2}$. Figure 6 presents the corresponding changes in $p \mathrm{CO}_{2}$ in the haemolymph and extrapallial fluid of all groups over time. The changes in $p \mathrm{CO}_{2}$ correlate with the observed changes in $\mathrm{pH}$ in both haemolymph and extrapallial fluid (Pearson correlation: $r=-0.51, n=96$, and $r=-0.37$, $n=96$, respectively). In contrast to extracellular $\mathrm{pH}$, the analysis of variance showed no significant impact of both temperature and $\mathrm{pH}$ for the haemolymph fluid in terms of $\mathrm{pCO}_{2}$ and large variability between replicates (Table 3 , Figure 6). Temperature appeared as a significant factor with no cumulative effect of $\mathrm{pH}$ for extrapallial $p \mathrm{CO}_{2}$ (Table 3).

All valves showed shell areas free of periostracum at or near the umbo, which may spread from there toward progressively

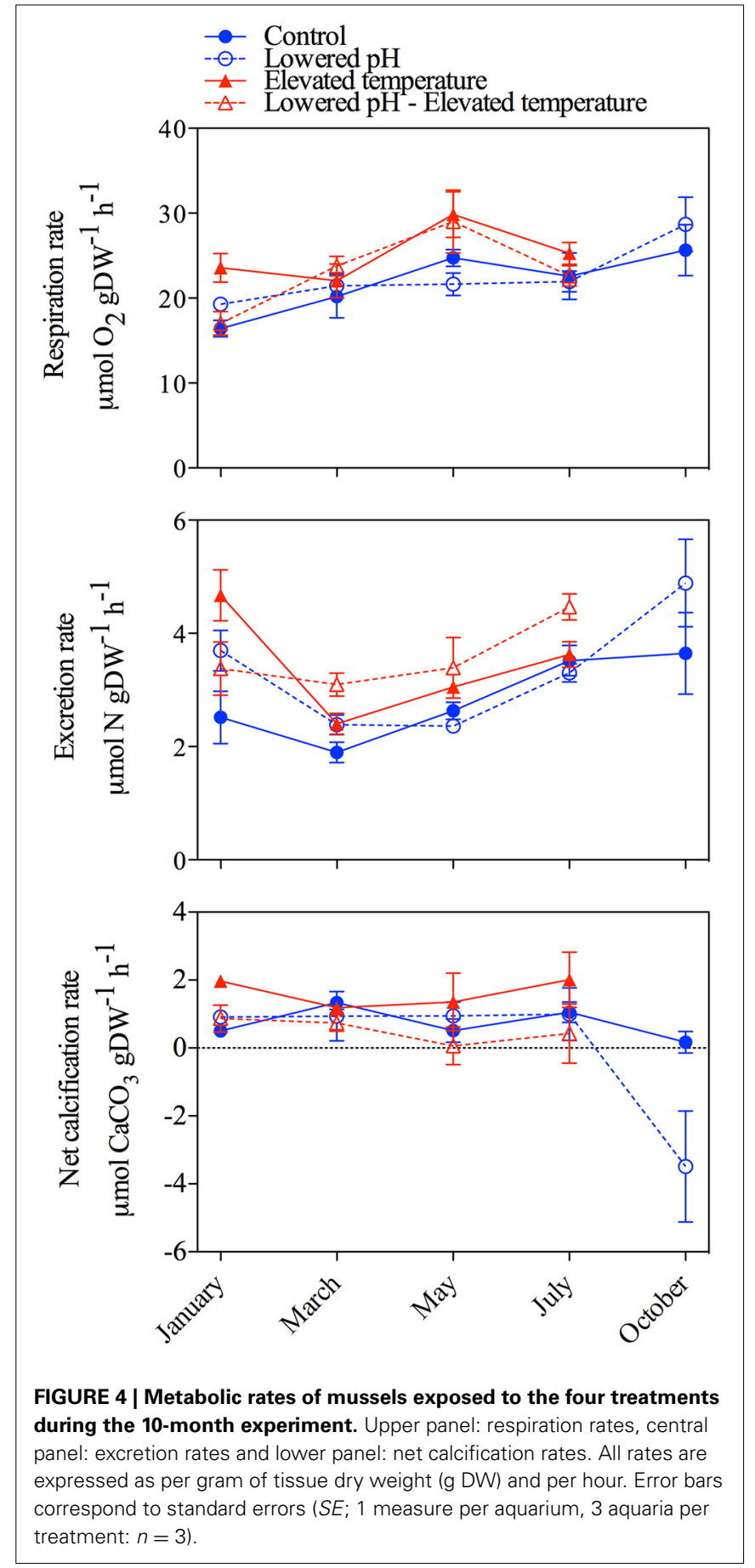

younger shell portions (Figure 7). Pristine periostracum is rather dark-blue to black, while the periostracum free zones are surrounded by a discolored periostracum with a beige taint. Average periostracum loss for the two treatments for which some mussels were still alive at the end of the experiment was $3.9 \pm 1.5 \%$ in the control and $16.9 \pm 6.7 \%$ in the lowered $\mathrm{pH}$ treatment. Periostracum discoloration was restricted to a narrow fringe around the periostracum free area in the control treatment, but was significantly increased in the lowered $\mathrm{pH}$ treatment (MannWhitney test, $p=0.002, n=10$ ), affecting $\sim 2 / 3$ of the shell area. 
Table 3 | Results of the permutational multivariate analyses of variance (Permanova) on metabolic rates and haemolymph/extrapallial fluid pH and $p \mathrm{CO}_{2}$ ( $n=54 ; 4$ time points, 2 temperature levels, $2 \mathrm{pH}$ levels).

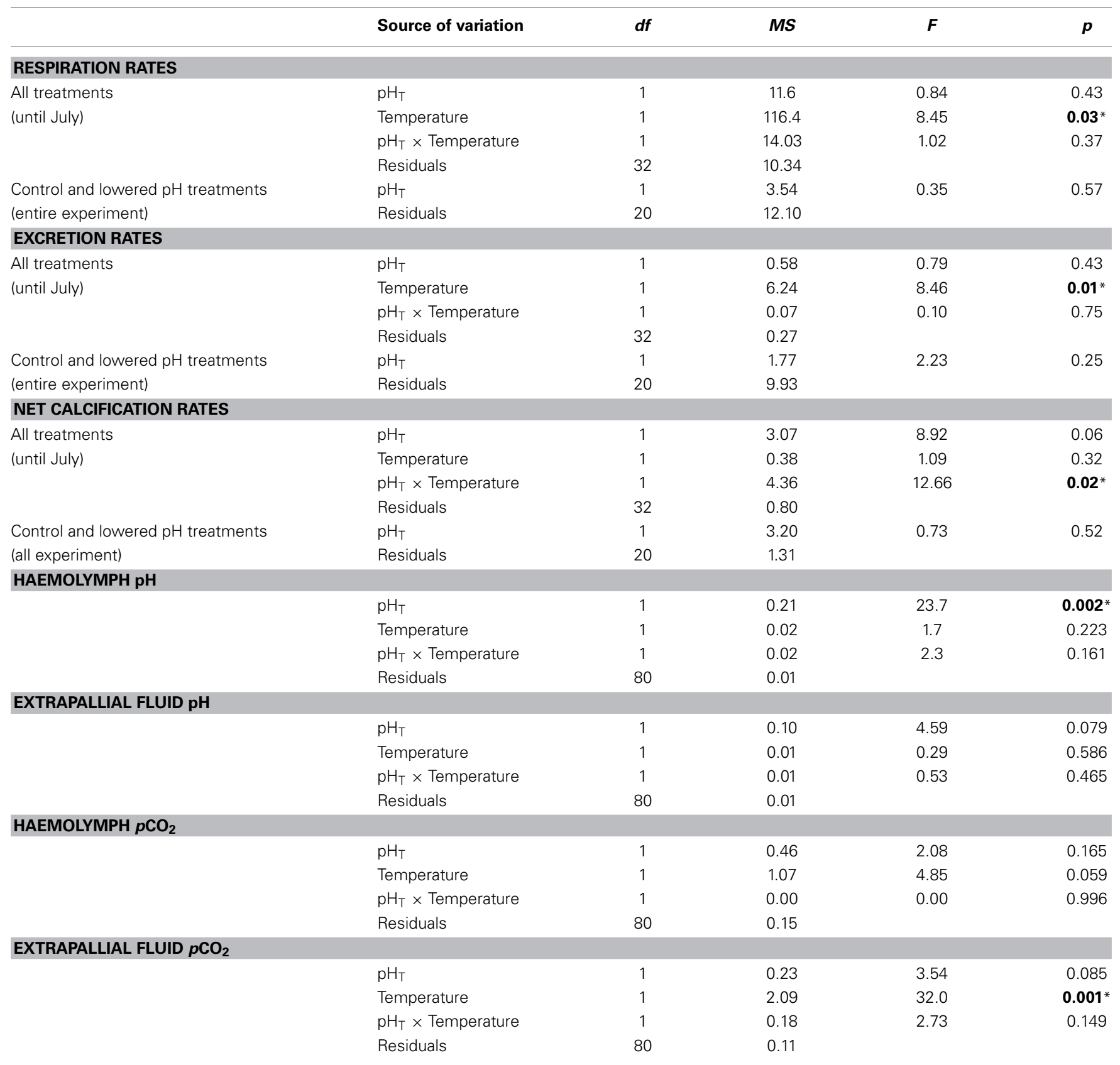

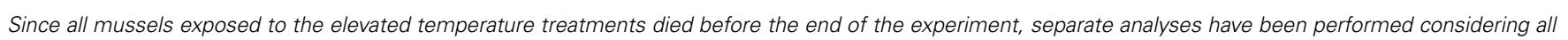

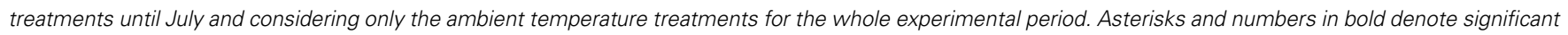
effects of the considered perturbation at the risk $\alpha=0.05$.

\section{DISCUSSION}

In the present work we tested the effects of OA and warming on growth physiology and survival of the Mediterranean mussel (Mytilus galloprovincialis). For the first time, this species has been exposed to $\mathrm{pH}$ and temperature levels that are projected for the end of the century by considering constant offsets of -0.3 $\mathrm{pH}$ units and $+3^{\circ} \mathrm{C}$ from ambient conditions. Based on these results, there is no doubt that mussels are highly sensitive to a $3^{\circ} \mathrm{C}$ warming that leads to suboptimal and even lethal temperature levels in summer. Increased mortality rates were recorded in July, when seawater temperature exceeded $\sim 25^{\circ} \mathrm{C}$ in the elevated temperature treatment. In this treatment, in August and September, seawater reached $\sim 28^{\circ} \mathrm{C}$, and all mussels died within few weeks. It must be stressed that increased mortality was also observed in summer (August and September) in the ambient temperature treatment, corresponding to temperature levels around 


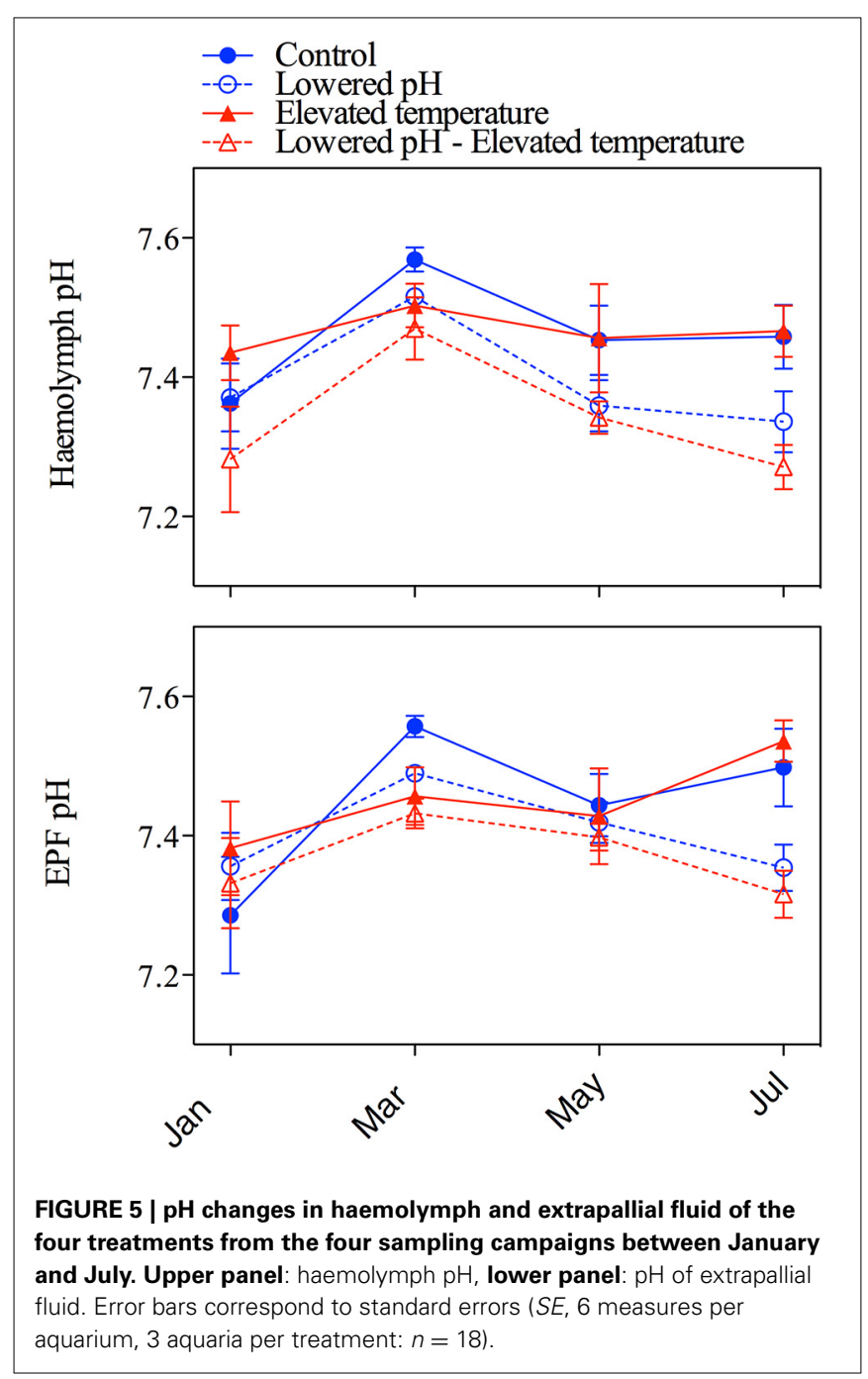

$25^{\circ} \mathrm{C}$. Temperature levels of $24-25^{\circ} \mathrm{C}$ have been identified, for this species, as an upper limit for normal physiological activities (Anestis et al., 2007, 2010) indicating that Mediterranean mussels already live close to their thermal acclimation limits (Anestis et al., 2007). Total mortality of mussels has been observed in Fangar Bay, located in the area where mussels used in the present study were sampled, when seawater temperature reached $28^{\circ} \mathrm{C}$ for more than 10 days (Ramón et al., 2007). In the last years, farmers from this area have already adapted their marketing strategy to increased summer temperature by selling their product earlier than in the previous years, thus avoiding the period of heat-induced mortalities (Ramón et al., 2005).

In contrast to warming, our results showed that acidification alone did not induce higher mortalities. The effects of $\mathrm{CO}_{2}$ can be twofold in organisms in environments such as intertidal or shallow subtidal zones. By exerting metabolic depression, $\mathrm{CO}_{2}$ can alleviate the level of stress and delay mortality through more efficient exploitation of energy reserves and passive tolerance. This is not corroborated by our results that do not show any significant delay in mortality at lowered $\mathrm{pH}$ levels. Conversely, it has been hypothesized that $\mathrm{OA}$, as an additional stressor, can narrow

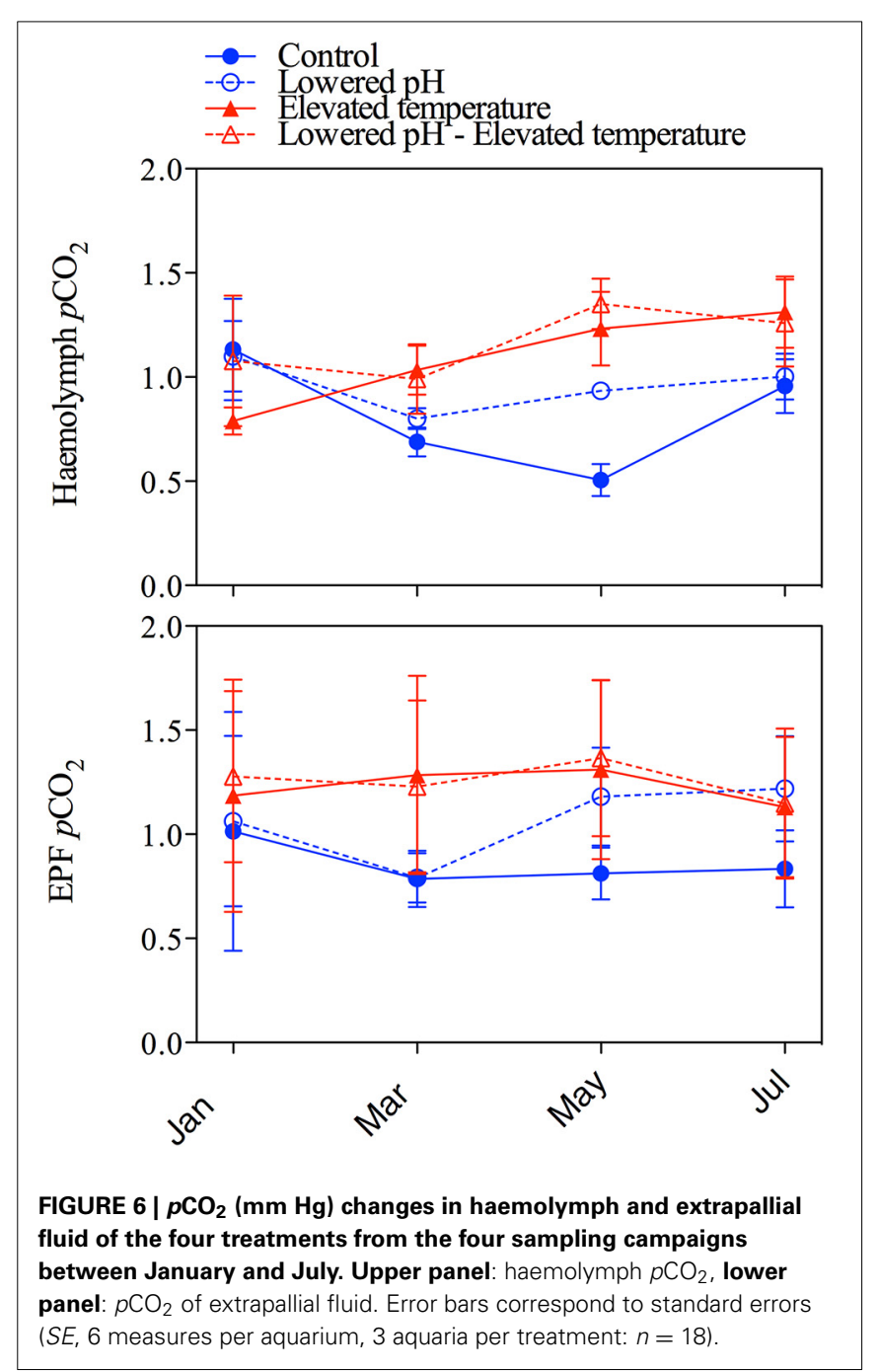

the thermal window of an organism (Pörtner and Farrell, 2008; Pörtner, 2012), by reducing aerobic performance, i.e., the range of active tolerance. This effect would become visible once the passive tolerance range is exploited sooner and faster at high temperature beyond the critical temperature of $25^{\circ} \mathrm{C}$. However, again, this was not observed in our study as the earlier onset in mortality at lowered $\mathrm{pH}$ and elevated temperature was not statistically significant. This absence of acidification effects on mussel survival is consistent with results reported by Range et al. (2012) who exposed juveniles of $M$. galloprovincialis to $\mathrm{pH}$ offsets of -0.3 and -0.6 for 84 days and also observed no impact on survival. In contrast, Bressan et al. (2014) observed a slight but significant increase in mortality after 6 months of experiment in the northern Adriatic Sea. However, it must be stressed that they exposed mussels to a much larger decrease in $\mathrm{pH}(0.7)$ than the one considered in our study. Our results therefore strongly suggest that survival of this species will not be affected by a $\mathrm{pH}$ decrease of $\sim 0.3$ in the Mediterranean Sea, predicted to occur within the present century.

According to our results, basic metabolic rates were also not impacted by $\mathrm{OA}$ alone while, as expected, they increased at 


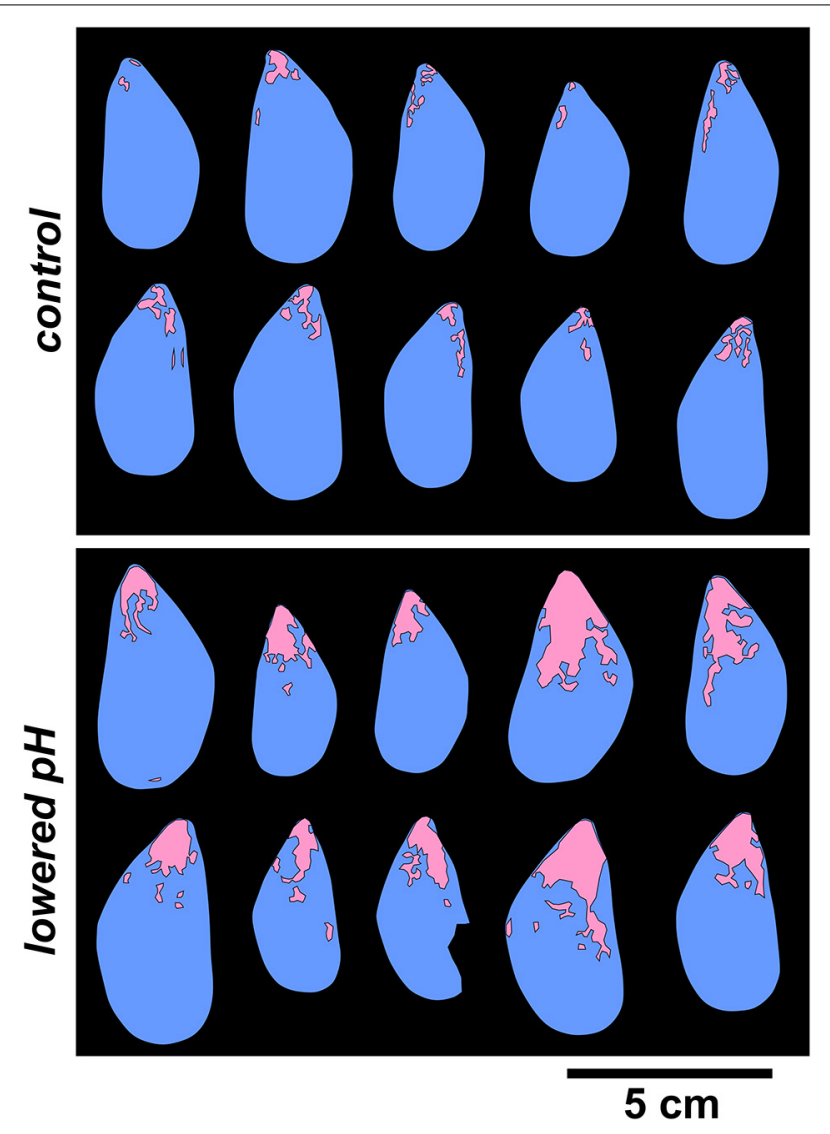

FIGURE 7 | Visual comparison of periostracum-free areas of the shell in the two experimental treatments at which some mussels were still alive at the end of the experiment (Control: upper panel and lowered $\mathrm{pH}$ treatment: lower panel).

elevated temperature. This is consistent with results from another experiment conducted on this species in the north Adriatic Sea (Range et al., 2014) that showed no effect of a pH decrease of 0.7 on both respiration and excretion rates. These results are not in line with the general theory of increased amino-acid metabolism and their decreased use in growth-related protein synthesis, which seems to be a typical response in marine invertebrates during hypercapnic acidosis (Pörtner et al., 1998; Michaelidis et al., 2005; Thomsen and Melzner, 2010). In another experiment conducted on Mediterranean mussels from the Atlantic coast in Portugal, respiration rates appeared again insensitive to acidification (water $\mathrm{pH}$ lowered by 0.3 and 0.6 compared to control treatment), but excretion rates increased at lowered levels of seawater $\mathrm{pH}$ (Fernandez-Reiriz et al., 2012).

The capacity of mollusks to compensate for changes in acidbase status due to elevated $\mathrm{CO}_{2}$ is believed to be somewhat limited (Melzner et al., 2009). In our experiment, in all groups, patterns of $\mathrm{pH}$ and $p \mathrm{CO}_{2}$ changes were similar in haemolymph and extrapallial fluid, confirming that the carbonate saturation status is similar in both body fluids (Thomsen et al., 2010). All groups displayed similar $\mathrm{pH}$ changes between spring and summer, however absolute values were different. The lowest extracellular $\mathrm{pH}$ values were observed in the elevated $\mathrm{CO}_{2}$ groups, in line with the low capacity of mussel species for extracellular acid base regulation, as previously observed (e.g., Michaelidis et al., 2005; Thomsen et al., 2010). For both body fluids, $\mathrm{pH}$ values displayed large seasonal changes in all groups, possibly reflecting shifting set points over time. The up-regulation of $\mathrm{pH}$ in spring (March sampling point), observed in all groups, may reflect transition from winter dormancy to enhanced activity, associated with an increase in the capacity for extracellular acid-base regulation, and likely, overall activity. Indeed, mussels reconstitute their energy reserves during the first quarter of the year before undergoing gametogenesis (Lowe et al., 1982). Furthermore, the seawater temperature from March to April was close to the optimum temperature of the species with critical thermal limits close to $25^{\circ} \mathrm{C}$ (Anestis et al., 2007). Any temperature change outside the optimum range will increase the baseline energy demand of an ectothermic animal and reduce e.g. the growth performance of the organism (oxygenand capacity-limited thermal tolerance (OCLTT; see Pörtner, 2010). Accordingly, the later sampling points under elevated seasonal temperatures led to a higher baseline energy demand (Guderley and Pörtner, 2010), visible as increased respiration and excretion rates. Moreover, elevated $\mathrm{CO}_{2}$ concentration caused a significant reduction in $\mathrm{pH}$ of the haemolymph in July. An exacerbation of uncompensated extracellular acidosis, in addition to the loss of the periostracum, could explain the negative calcification rates measured in October (see thereafter). Unfortunately, high mortality prevented measurements of extracellular $\mathrm{pH}$ during this period. The exacerbation of uncompensated extracellular acidosis, as observed in July, suggests a progressive insufficiency in acid-base regulation capacity at elevated temperatures and $p \mathrm{CO}_{2}$ levels, conditions that will prevail in the future high $\mathrm{CO}_{2}$ ocean, affecting the species at the warm end of their distribution range. However, as will be discussed below, the significant decrease of seawater $\mathrm{pH}$ in the lowered $\mathrm{pH}$ treatment during this summer period could have been also responsible for these lowered compensation capacities and growth.

Somatic and shell growth did not appear highly sensitive to OA and warming during most of the experiment. It must be stressed that growth was very limited and much lower than what can be measured in aquaculture sites in the Mediterranean Sea (i.e., 20-40 $\mathrm{mm} \mathrm{yr}^{-1}$; Sarà et al., 1998). Although feeding rates were calculated based on in situ ingestion rates, maintaining mussels in the laboratory is challenging and optimal growth rates could not be reached with a feeding protocol using only a few phytoplankton species. It appears essential, in order to improve risk assessment for the Mediterranean aquaculture industry and for designing related adaptation strategies, to conduct future perturbation experiments, for instance using FOCE systems (Gattuso et al., 2014), directly in the field near aquaculture sites. Net calcification rates as estimated by a modified alkalinity anomaly technique showed positive values under all treatments during most of the experiment, except after summer when negative values (net dissolution) were measured in the lowered $\mathrm{pH}$ treatment. The visual analysis of the shells indeed showed that mussels exposed to lowered $\mathrm{pH}$ levels had much larger areas of their shells free of periostracum (Figure 7). This organic layer plays the role of shell protection and can be partially lost as a natural result 
of abrasion from the bivalve's movements. However, our results suggest, in accordance with findings by Rodolfo-Metalpa et al. (2011), that the periostracum is altered when mussels are exposed to lowered $\mathrm{pH}$ conditions. For these mussels, calcitic and aragonitic shell layers were then more exposed to the surrounding seawater and consequently more subject to corrosion, partially explaining the observed net dissolution rates and the decrease of shell weight in low $\mathrm{pH}$ treatments after summer. This could reduce the resistance of the shell to mechanical damage, enhancing the risk of predation (Reimer and Tedengren, 1996; Aronhime and Brown, 2009) and of damage by storms and associated wave action (Nehls and Thiel, 1993). Furthermore, although no systematic data have been gathered on this aspect, mussels from all aquaria were able to group and attach to each other with their byssus during most of the experiment, while mussels exposed to low $\mathrm{pH}$ conditions after summer were unable to do so and it was possible to easily pick them out of the aquarium individually. This could be due to weaker and less extensible byssal threads for mussels maintained at a lowered $\mathrm{pH}$, as shown by O'donnell et al. (2013) on mussels from the US West coast. Weaker byssal threads negatively affect the ability of mussels to attach to substrate, thereby increasing the probability to be displaced due to hydrodynamic forces generated by storms, which is a significant cause of mortality in the field (Carrington et al., 2009).

Although, as already mentioned, growth was limited in our study, lower net calcification rates, and growth under lowered $\mathrm{pH}$ levels in summer have been observed and are consistent with Kroeker et al. (2014) who recently reported significant effects of acidification on M. galloprovincialis shell growth after one month exposure at a $\mathrm{pH}$ level maintained at an offset of $\sim-0.3$ as compared to control conditions. However, this study, conducted over a relatively short exposure time and at lower temperature levels than in our experiment, showed that warming (from 14 to $20^{\circ} \mathrm{C}$ ) mitigated this negative acidification effect as a consequence of both physiological (performances such as calcification increase if warming occurs at temperatures below the thermal optimum, Pörtner, 2012) and chemical ( $\mathrm{pH}$ and saturation states increase with temperature) effects. Such mitigation effects of warming were not be observed during our study that was conducted under higher temperature levels. In contrast, and more in line with our results, a decrease in shell calcification for this species has been shown as a consequence of synergistic impacts of elevated $p \mathrm{CO}_{2}$ and temperature on the same species by Rodolfo-Metalpa et al. (2011). However, based on our experiment, we cannot elucidate if the decrease in net calcification rates and growth as observed after summer is a consequence of lower $\mathrm{pH}$ levels during that period ( $\mathrm{pH}$ offsets of -0.4 vs. -0.3 during the rest of the experiment) or a consequence of a combined effect of acidification and warming as suggested by Rodolfo-Metalpa et al. (2011).

To conclude, this study is the first focused on the combined effects of warming and acidification on the Mediterranean mussel over seasonal exposure time. Our results strongly suggest that ongoing ocean warming and more frequent summer heat waves will be serious threats to this species in the Mediterranean Sea. All in all, OA does not seem to have very serious impacts on this species in this alkaline region although our results suggest lower growth rates, lower acid-base regulation capacities and significant loss of the periostracum cover in summer coinciding with temperatures beyond optimal levels. Based on the present dataset, the question whether decreased growth capacities are due to a combined effect of $\mathrm{OA}$ and warming remains however unresolved. More long-term experiments performed at proximity of aquaculture sites and combining these two stressors are still necessary to improve risk assessment for the Mediterranean aquaculture industry and for designing related adaptation strategies.

\section{ACKNOWLEDGMENTS}

We like to thank Zora Zittier for her help with the body fluid measurements during the sampling in January, Jean-Pierre Gattuso for help with experimental design and Jean-Olivier Irisson for help with statistics. We wish to thank Claudia R. BenitezNelson and Emily Carrington for their constructive reviews. This work was funded by the EC FP7 project "Mediterranean Sea Acidification in a changing climate" (MedSeA; grant agreement 265103), the French program PNEC (Programme national environnement côtier; Institute national des sciences de l'univers) and the EC FP7 project "European Project on Ocean Acidification" (EPOCA; grant agreement 211384).

\section{REFERENCES}

Anestis, A., Lazou, A., Portner, H. O., and Michaelidis, B. (2007). Behavioral, metabolic, and molecular stress responses of marine bivalve Mytilus galloprovincialis during long-term acclimation at increasing ambient temperature. Am. J. Physiol. Regul. Integr. Comp. Physiol. 293, R911-R921. doi: 10.1152/ajpregu.00124.2007

Anestis, A., Pörtner, H. O., Karagiannis, D., Angelidis, P., Staikou, A., and Michaelidis, B. (2010). Response of Mytilus galloprovincialis (L.) to increasing seawater temperature and to marteliosis: metabolic and physiological parameters. Comp. Biochem. Physiol. A 156, 57-66. doi: 10.1016/j.cbpa.2009.12.018

Aronhime, B. R., and Brown, K. M. (2009). The roles of profit and claw strength in determining mussel size selection by crabs. J. Exp. Mar. Biol. Ecol. 379, 28-33. doi: 10.1016/j.jembe.2009.08.012

Bressan, M., Chinellato, A., Munari, M., Matozzo, V., Manci, A., Marèeta, T., et al. (2014). Does seawater acidification affect survival, growth and shell integrity in bivalve juveniles? Mar. Environ. Res. 99, 136-148. doi: 10.1016/j.marenvres. 2014.04.009

Carrington, E., Moeser, G. M., Dimond, J., Mello, J. J., and Boller, M. L. (2009). Seasonal disturbance to mussel beds: field test of a mechanistic model predicting wave dislodgment. Limnol. Oceanogr. 54, 978-986. doi: 10.4319/lo.2009.54.3.0978

Ciais, P., Sabine, C., Bala, G., Bopp, L., Brovkin, V., Canadell, J., et al. (2013). "Carbon and other biogeochemical cycles," in Climate Change 2013: the Physical Science Basis. Contribution of Working Group I to the Fifth Assessment Report of the Intergovernmental Panel on Climate Change, eds T. F. Stocker, D. Qin, G.-K. Plattner, M. Tignor, S. K. Allen, and J. Boschung, et al. (Cambridge; New York: Cambridge University Press), 465-570.

Collins, M., Knutti, R., Arblaster, J., Dufresne, J.-L., Fichefe, T., Friedlingstein, P. et al. (2013). "Long-term climate change: projections, commitments and irreversibility," in Climate Change 2013: the Physical Science Basis. Contribution of Working Group I to the Fifth Assessment Report of the Intergovernmental Panel on Climate Change, eds T. F. Stocker, D. Qin, G.-K. Plattner, M. Tignor, S. K. Allen, J. Boschung, et al. (Cambridge; New York: Cambridge University Press), 1029-1136.

Dickson, A. G., Sabine, C. L., and Christian, J. R. (2007). Guide to Best Practices for Ocean $\mathrm{CO}_{2}$ Measurements. Vol. 3, PICES Special Publication, 191.

Duarte, C., Navarro, J. M., Acuna, K., Torres, R., Manriquez, P. H., Lardies, M. A., et al. (2014). Combined effects of temperature and ocean acidification on the juvenile individuals of the mussel Mytilus chilensis. J. Sea Res. 85, 308-314. doi: 10.1016/j.seares.2013.06.002

FAO. (2014). The State of World Fisheries and Aquaculture (SOFIA). Rome: Fisheries and Aquaculture Department. 
Fernandez-Reiriz, M. J., Range, P., Alvarez-Salgado, X. A., Espinosa, J., and Labarta, U. (2012). Tolerance of juvenile Mytilus galloprovincialis to experimental seawater acidification. Mar. Ecol. Prog. Ser. 454, 65-74. doi: 10.3354/meps09660

Galimany, E., Ramón, M., and Ibarrola, I. (2011). Feeding behavior of the mussel Mytilus galloprovincialis (L.) in a Mediterranean estuary: a field study. Aquaculture 314, 236-243. doi: 10.1016/j.aquaculture.2011.01.035

Gattuso, J.-P., and Hansson, L. (2011). "Ocean acidification: background and history," in Ocean Acidification, eds J.-P. Gattuso and L. Hansson (Oxford: Oxford University Press), 1-20.

Gattuso, J.-P., Kirkwood, W., Barry, J. P., Cox, E., Gazeau, F., Hansson, L., et al. (2014). Free-ocean $\mathrm{CO}_{2}$ enrichment (FOCE) systems: present status and future developments. Biogeosciences 11, 4057-4075. doi: 10.5194/bg-114057-2014

Gazeau, F., Parker, L. M., Comeau, S., Gattuso, J.-P., O'connor, W. A., Martin, S., et al. (2013). Impacts of ocean acidification on marine shelled molluscs. Mar. Biol. 160, 2207-2245. doi: 10.1007/s00227-013-2219-3

Gazeau, F., Quiblier, C., Jansen, J. M., Gattuso, J.-P., Middelburg, J. J., and Heip, C. H. R. (2007). Impact of elevated $\mathrm{CO}_{2}$ on shellfish calcification. Geophys. Res. Lett. 34, L07603. doi: 10.1029/2006GL028554

Guderley, H., and Pörtner, H. O. (2010). Metabolic power budgeting and adaptive strategies in zoology: examples from scallops and fish. Can. J. Zool. 88, 753-763. doi: 10.1139/Z10-039

Hervé, M. (2014). RVAideMemoire: Diverse Basic Statistical and Graphical Functions. Available online at: http://cran.r-project.org/web/packages/RVAideMemoire/ index.html

Hiebenthal, C., Philipp, E. E. R., Eisenhauer, A., and Wahl, M. (2013). Effects of seawater $\mathrm{pCO}_{2}$ and temperature on shell growth, shell stability, condition and cellular stress of Western Baltic Sea Mytilus edulis (L.) and Arctica islandica (L.). Mar. Biol. 160, 2073-2087. doi: 10.1007/s00227-012-2080-9

Hofmann, G. E., Smith, J. E., Johnson, K. S., Send, U., Levin, L. A., Micheli, F., et al. (2011). High-frequency dynamics of ocean $\mathrm{pH}$ : a multi-ecosystem comparison. PLoS ONE 6:e28983. doi: 10.1371/journal.pone.0028983

Ivanina, A. V., Dickinson, G. H., Matoo, O. B., Bagwe, R., Dickinson, A., Beniash, E., et al. (2013). Interactive effects of elevated temperature and $\mathrm{CO}_{2}$ levels on energy metabolism and biomineralization of marine bivalves Crassostrea virginica and Mercenaria mercenaria. Comp. Biochem. Physiol. Mol. Integr. Physiol. 166, 101-111. doi: 10.1016/j.cbpa.2013.05.016

Jorda, G., Marba, N., and Duarte, C. M. (2012). Mediterranean seagrass vulnerable to regional climate warming. Nat. Clim. Change 2, 821-824. doi: 10.1038/nclimate1533

Kroeker, K. J., Gaylord, B., Hill, T. M., Hosfelt, J. D., Miller, S. H., and Sanford, E. (2014). The role of temperature in determining species' vulnerability to ocean acidification: a case study using Mytilus galloprovincialis. PLoS ONE 9:e100353. doi: 10.1371/journal.pone.0100353

Lavigne, H., Epitalon, J. M., and Gattuso, J.-P. (2014). Seacarb: Seawater Carbonate Chemistry with R. Available online at: http:/CRAN.R-project.org/ package $=$ seacarb

Le Quéré, C., Raupach, M. R., Canadell, J. G., Marland, G., Bopp, L., Ciais, P., et al. (2009). Trends in the sources and sinks of carbon dioxide. Nat. Geosci. 2, 831-836. doi: 10.1038/ngeo689

Lima, F. P., and Wethey, D. S. (2012). Three decades of high-resolution coastal sea surface temperatures reveal more than warming. Nat. Commun. 3, 704. doi: $10.1038 /$ ncomms 1713

Lowe, D. M., Moore, M. N., and Bayne, B. L. (1982). Aspects of gametogenesis in the marine mussel Mytilus edulis L. J. Mar. Biol. Assoc. U.K. 62, 133-145. doi: $10.1017 /$ S0025315400020166

Mackenzie, C. L., Ormondroyd, G. A., Curling, S. F., Ball, R. J., Whiteley, N. M., and Malham, S. K. (2014). Ocean warming, more than acidification, reduces shell strength in a commercial shellfish species during food limitation. PLoS ONE 9:e86764. doi: 10.1371/journal.pone.0086764

Marba, N., and Duarte, C. M. (2010). Mediterranean warming triggers seagrass (Posidonia oceanica) shoot mortality. Glob. Change Biol. 16, 2366-2375. doi: 10.1111/j.1365-2486.2009.02130.x

Melzner, F., Gutowska, M. A., Hu, M., and Stumpp, M. (2009). Acid-base regulatory capacity and associated proton extrusion mechanisms in marine invertebrates: an overview. Comp. Biochem. Physiol. Mol. Integr. Physiol. 153A, S80-S80. doi: 10.1016/j.cbpa.2009.04.056

Michaelidis, B., Ouzounis, C., Paleras, A., and Pörtner, H. O. (2005). Effects of long-term moderate hypercapnia on acid-base balance and growth rate in marine mussels Mytilus galloprovincialis. Mar. Ecol. Prog. Ser. 293, 109-118. doi: 10.3354/meps293109

Nehls, G., and Thiel, M. (1993). Large-scale distribution patterns of the mussel Mytilus edulis in the Wadden Sea of Schleswig-Holstein: do storms structure the ecosystem? Netherlands J. Sea Res. 31, 181-187. doi: 10.1016/0077-7579(93) 90008-G

O'donnell, M. J., George, M. N., and Carrington, E. (2013). Mussel byssus attachment weakened by ocean acidification. Nat. Clim. Change 3, 587-590. doi: $10.1038 /$ nclimate 1846

Orr, J. C. (2011). "Recent and future changes in ocean carbonate chemistry," in Ocean Acidification, eds J.-P. Gattuso and L. Hansson (Oxford: Oxford University Press), 41-66.

Pörtner, H. O. (2010). Oxygen- and capacity-limitation of thermal tolerance: a matrix for integrating climate-related stressor effects in marine ecosystems. J. Exp. Biol. 213, 881-893. doi: 10.1242/jeb.037523

Pörtner, H.-O. (2012). Integrating climate-related stressor effects on marine organisms: unifying principles linking molecule to ecosystem-level changes. Mar. Ecol. Prog. Ser. 470, 273-290. doi: 10.3354/meps10123

Pörtner, H.-O., Bickmeyer, U., Bleich, M., Bock, C., Brownlee, C., Melzner, F., et al. (2010). "Studies of acid-base status and regulation, p137-166," in Guide to Best Practices for Ocean Acidification Research and Data Reporting, eds U. Riebesell, V. J. Fabry, L. Hansson, and J.-P. Gattuso (Publications Office of the European Union), 260. Available online at: http://www.epoca-project.eu/index. php/Home/Guide-to-OA-Research/

Pörtner, H.-O., Boutilier, R. G., Tang, Y., and Toews, D. P. (1990). Determination of intracellular $\mathrm{pH}$ and $p \mathrm{CO}_{2}$ after metabolic inhibition by fluoride and nitrilotriacetic acid. Respir. Physiol. 81, 255-274. doi: 10.1016/0034-5687(90)90050-9

Pörtner, H. O., and Farrell, A. P. (2008). Physiology and climate change. Science 322, 690-692. doi: 10.1126/science. 1163156

Pörtner, H. O., Langenbuch, M., and Reipschlager, A. (2004). Biological impact of elevated ocean $\mathrm{CO}_{2}$ concentrations: lessons from animal physiology and earth history. J. Oceanogr. 60, 705-718. doi: 10.1007/s10872-004-5763-0

Pörtner, H. O., Reipschläger, A., and Heisler, N. (1998). Acid-base regulation, metabolism and energetics in Sipunculus nudus as a function of ambient carbon dioxide level. J. Exp. Biol. 201, 43-55.

Ramón, M., Cano, J., Peña, J. B., and Campos, M. J. (2005). Current status and perspectives of mollusc (bivalves and gastropods) culture in the Spanish Mediterranean. Boletin Instituto Español de Oceanografia 21, 361-373.

Ramón, M., Fernandez, M., and Galimany, E. (2007). Development of mussel (Mytilus galloprovincialis) seed from two different origins in a semienclosed Mediterranean Bay (NE Spain). Aquaculture 264, 148-159. doi: 10.1016/j.aquaculture.2006.11.014

Range, P., Chícharo, M. A., Ben-Hamadou, R., Piló, D., Fernandez-Reiriz, M. J., Labarta, U., et al. (2014). Impacts of $\mathrm{CO}_{2}$-induced seawater acidification on coastal Mediterranean bivalves and interactions with other climatic stressors. Reg. Environ. Change 14, 19-30. doi: 10.1007/s10113-0130478-7

Range, P., Piloì, D., Ben-Hamadou, R., Chì̀Charo, M. A., Matias, D., Joaquim, $S$ et al. (2012). Seawater acidification by $\mathrm{CO}_{2}$ in a coastal lagoon environment: effects on life history traits of juvenile mussels Mytilus galloprovincialis. J. Exp. Mar. Biol. Ecol. 424-425, 89-98. doi: 10.1016/j.jembe.2012. 05.010

Reimer, O., and Tedengren, M. (1996). Phenotypical improvement of morphological defences in the mussel Mytilus edulis induced by exposure to the predator Asteria rubens. Oikos 75, 383-390. doi: 10.2307/3545878

Rhein, M., Rintoul, S. R., Aoki, S., Campos, E., Chambers, D., Feely, R. A., et al. (2013). “Observations: ocean,” in Climate Change 2013: the Physical Science Basis. Contribution of Working Group I to the Fifth Assessment Report of the Intergovernmental Panel on Climate Change, eds T. F. Stocker, D. Qin, G.-K. Plattner, M. Tignor, S. K. Allen, J. Boschung, et al. (Cambridge; New York: Cambridge University Press), 255-332.

Rodolfo-Metalpa, R., Houlbrèque, F., Tambutté, E., Boisson, F., Baggini, C., Patti, F. P., et al. (2011). Coral and mollusc resistance to ocean acidification adversely affected by warming. Nat. Clim. Change 1, 308-312. doi: 10.1038/ nclimate 1200

Sarà, G., Manganaro, A., Cortese, G., Pusceddu, A., and Mazzola, A. (1998). The relationship between food availability and growth in Mytilus galloprovincialis in the open sea (southern Mediterranean). Aquaculture 167, 1-15. doi: 10.1016/S0044-8486(98)00281-6 
Spencer Davies, P. (1989). Short-term growth measurements of corals using an accurate buoyant weighing technique. Mar. Biol. 101, 389-395. doi: 10.1007/BF00428135

Talmage, S. C., and Gobler, C. J. (2011). Effects of elevated temperature and carbon dioxide on the growth and survival of larvae and juveniles of three species of Northwest Atlantic bivalves. PLoS ONE 6:e26941. doi: 10.1371/journal.pone.0026941

The Mermex Group. (2011). Marine ecosystems' responses to climatic and anthropogenic forcings in the Mediterranean. Prog. Oceanogr. 91, 97-166. doi: 10.1016/j.pocean.2011.02.003

Thomsen, J., Gutowska, M. A., Saphorster, J., Heinemann, A., Trubenbach, K., Fietzke, J., et al. (2010). Calcifying invertebrates succeed in a naturally $\mathrm{CO}_{2}$ rich coastal habitat but are threatened by high levels of future acidification. Biogeosciences 7, 3879-3891. doi: 10.5194/bg-7-3879-2010

Thomsen, J., and Melzner, F. (2010). Moderate seawater acidification does not elicit long-term metabolic depression in the blue mussel Mytilus edulis. Mar. Biol. 157, 2667-2676. doi: 10.1007/s00227-010-1527-0

Touratier, F., and Goyet, C. (2011). Impact of the Eastern Mediterranean Transient on the distribution of anthropogenic $\mathrm{CO}_{2}$ and first estimate of acidification for the Mediterranean Sea. Deep-Sea Res. I Oceanogr. Res. Papers 58, 1-15. doi: 10.1016/j.dsr.2010.10.002

Watson, S. A., Southgate, P. C., Miller, G. M., Moorhead, J. A., and Knauer, J. (2012). Ocean acidification and warming reduce juvenile survival of the fluted giant clam, Tridacna squamosa. Molluscan Res. 32, 177-180.
Wolf-Gladrow, D. A., Zeebe, R. E., Klaas, C., Körtzinger, A., and Dickson, A. G. (2007). Total alkalinity: the explicit conservative expression and its application to biogeochemical processes. Mar. Chem. 106, 287-300. doi: 10.1016/j. marchem.2007.01.006

Conflict of Interest Statement: The authors declare that the research was conducted in the absence of any commercial or financial relationships that could be construed as a potential conflict of interest.

Received: 31 July 2014; accepted: 03 November 2014; published online: 26 November 2014.

Citation: Gazeau F, Alliouane S, Bock C, Bramanti L, López Correa M, Gentile M, Hirse T, Pörtner H-O and Ziveri P (2014) Impact of ocean acidification and warming on the Mediterranean mussel (Mytilus galloprovincialis). Front. Mar. Sci. 1:62. doi: 10.3389/fmars.2014.00062

This article was submitted to Global Change and the Future Ocean, a section of the journal Frontiers in Marine Science.

Copyright (C) 2014 Gazeau, Alliouane, Bock, Bramanti, López Correa, Gentile, Hirse, Pörtner and Ziveri. This is an open-access article distributed under the terms of the Creative Commons Attribution License (CC BY). The use, distribution or reproduction in other forums is permitted, provided the original author(s) or licensor are credited and that the original publication in this journal is cited, in accordance with accepted academic practice. No use, distribution or reproduction is permitted which does not comply with these terms. 